\title{
Centraleuropas manglende politiske kultur
}

\section{Dana Schmidt}

\begin{abstract}
Det går fremad for økonomien i de ekskommunistiske lande i Centraleuropa. Men skandaler, korruption og demagogi er stadig en del af regionens hverdag
\end{abstract}

"Det går godt, og det bliver endnu bedre", sagde Polens regeringschef, Jaroslaw Kaczynski, da han forleden vurderede sit lands udvikling i det seneste år. Altså siden hans konservative parti Ret og Retfærdighed, PiS, og dets katolske/euroskeptiske partnere kom til magten og erklærede, at det vil reformere Polen, gøre det både rigere og mere demokratisk og moralsk og rense det for kommunisternes indflydelse. Det trængte landet til efter årene under det postkommunistiske Demokratiske Venstreforbund, SDL, hed det dengang.

Men både en masse almindelige polakker og mange oppositionspolitikere er uenige med de fine karakterer, som premierministeren bedømmer sin egen og sin tvillingebror, præsident Lech Kaczynskis, indsats med. Kritikken gælder både uopfyldte løfter om lønstigninger og nye boliger, men også broderstyrets pinlige korruptionsaffære - et forsøg på at 'købe' en oppositionspolitiker, som en privat tv-kanal optog med skjult kamera og viste flere gange. PiS' popularitet faldt omgående fra 30 til 18 procent, og en demonstration i Warszawa samlede over 10.000 mennesker, blandt dem tidligere PiS-tilhængere. Vi skammer os for Polen, råbte masserne.

Også regeringens demonstrative katolicisme, som især koalitionspartiet Polske Familiers Liga står for, irriterer stadig flere polakker. Selv en del af de troende synes, at det er for meget, at Liga-folkene nægter at hilse på homoseksuelle, og at præsidenten og regeringschefen accepterer det. Og en række videnskabsmænd, deriblandt katolske, har åbent protesteret mod den ultrakon- 
servative viceundervisningsminister Miroslaw Orzechowskis forslag om at forbyde evolutionsteorien i skolernes pensum. Også tvillingernes EU-modstand - en kendt erklæring i den forbindelse er Lech Kaczynskis "Europa er ikke mit hjemland" vækker stadig flere negative reaktioner.

"Jeg skammer mig ikke over Polen, det har jeg aldrig gjort. Men jeg er flov over dem, som i dag hersker i mit land. Jeg skammer mig over, hvad vores politikere siger i EU, som de samtidig forlanger så mange penge som muligt fra, jeg er flov over deres demagogi og mangel på politisk kultur", sagde den fhv. dissident og senere Polens udenrigsminister Bronislaw Geremek i oktober, da han deltog i Forum 2000 i Prag.

Det er et årligt symposium, som Tjekkiets ekspræsident, Vaclav Havel, står for, og som hver gang tiltrækker prominente kulturpersonligheder, politologer etc. fra hele verden. I år var 'demokratiets krise', som flere deltagere kaldte situationen i Centraleuropa, et af de store emner. Også Geremek brugte det udtryk og sagde, at hele Visegradgruppen (Polen, Tjekkiet, Slovakiet og Ungarn, red.) befinder sig i en kriseperiode, hvor demagogi og populisme vinder over politisk visdom.

"Årsagen til det er, at vi har forsømt opbygningen af politisk kultur og et bevidst borgersamfund. Vi har ganske vist formået at etablere demokratiske politiske institutioner, men det er ikke nok. Se bare, hvad der sker i Polen. Omkring 80 procent polakker går ind for $\mathrm{EU}$, men de har stemt på anti-europæiske politikere, altså ladet sig friste af deres populistiske løfter”, sagde Geremek. Og udtrykte forhåbning om, at det centraleuropæiske demokratis 'sygdom' ikke vil vare længere end de nuværende regeringers embedsperioder.

\section{Foragt for politikerne}

Hvad sker der egentlig i Visegrad ud over hyperkatolismen og den påståede moralske oprustning i regionens kolos Polen, som også er EU's sjettestørste land, men hvis ledere ikke vil tale Europas sprog? Hvad præger regionen 17 år efter kommunistregimets fald og snart to år efter indtrædelse i EU?

Skandaler a la den ungarske regeringschef Ferenc Gyrcsanys løgnaffære eller lederen af det slovakiske Nationalparti, Jan Slotas, perfide og provokative udtalelser om ungarere. Et korruptionsniveau, som langt overstiger de vestlige landes. Gentagne regeringskriser og en næsten permanent valgkamp, ofte med beskidte midler, som i Tjekkiet eller Polen. Populismens og nationalismens opblomstring som i Slovakiet og Ungarn. Det er nogle af de fænomener, som iagttagere påpeger hyppigst og folk kritiserer mest.

Men almindelige mennesker taler også meget om politikernes arro- 
gance og sociale kynisme - forskellen mellem politikernes og de allerfleste borgeres levestandard er himmelvid. Selv de folkevalgte hører meget mere til den nyrige overklasse end til folket - i Tjekkiet fx får parlamentarikerne 70-80.000 koruna (17-20.000 kroner inkl. forskellige tillæg) om måneden. Det er fem gange mere end en reel gennemsnitsmånedsløn, og det bliver nok ikke anderledes i den nærmeste fremtid.

"Spørgsmålet har ikke nogen høj prioritet for tiden", sagde næstformanden for kristne demokrater, Jan Kasal, i oktober, da Tjekkiets førende dagblad, Dnes, spurgte til parlamentets løfte fra 2004 om en indefrysning af medlemmernes lønninger. Den kom aldrig - tværtimod stiger deres løn fra 1. januar med ca. ti procent. Den er en hån mod befolkningen, siger mange tjekker.

De tjekkiske politikeres prioritet er at forberede landet til et valg $i$ utide og kreere en overgangsregering, som kan holde så længe. Et normalt ministerkabinet er det ikke lykkedes at danne siden valget, som fandt sted i juni og blev vundet af det oppositionelle Borgernes Demokratiske Parti (ODS). Resultatet var helt lovligt, men hovedtaberen, den socialdemokratiske regeringschef Jiri Paroubek, gik amok og råbte om et kup a la kommunisternes magtovertagelse i 1948.

"Det er også et eksempel på politisk kultur. I nabolandet Østrig siger valgets taber, Wolfgang Schüssel, til lykke til vinderen, hos os bliver han vred og fornærmet", siger fhv. tjekkiske LO-formand og nu EU-parlamentariker, Richard Falbr.

Paroubek har lige siden blokeret for dannelse af en anden regering end en under hans ledelse, men nu er han ved at give sig, for selv flere af hans partifæller er begyndt at kritisere hans adfærd. Partiet selv har det heller ikke godt efter et stort nederlag ved kommunale valg og flere pinlige korruptionsskandaler. I to af dem figurerer Paroubeks fhv. kontorchef og toprådgiver, Zdenek Dolezel, som sammen med et par andre socialdemokrater planlagde et milliontyveri fra EU-fonde, men blev afsløret i oktober af en privat tv-kanal. Med skjult kamera, ligesom kollegerne i Polen gjorde med PiS' forhandlinger med en oppositionspolitiker.

Også i Ungarn var det journalister, som afslørede premierministerens affære. Det var dog uden kamera - statsradioen sørgede for det.

Stationen udsendte i september optagelsen af et møde i socialistpartiet, hvor Ferenc Guyrcsany indrømmer at have løjet for befolkningen om landets $\varnothing$ konomi for at sikre sig et genvalg ved parlamentsvalget i april.

"Vi løj om morgenen, om dagen og om aftenen", kunne hele Ungarn høre ham sige.

Hans udtalelse, som kaldes 'sandhed om løgn', har fremkaldt de 
største demonstrationer siden kommunismens kollaps og inspireret oppositionen til kræve Guyrcsanys afgang. Protesterne fortsatte i flere uger og overskyggede delvist markeringen af jubilæet for folkeopstanden i 1956, men regeringschefen klarede krisen, fordi parlamentet bakkede ham op.

Men ved efterfølgende kommunalvalg tabte socialisterne, og oppositionspartiet Fidesz jublede og betegnede sin sejr som et tegn på, at de også ville vinde et evt. parlamentsvalg i utide. Et valg er dog ikke sandsynligt. Guyrcsany, i øvrigt en af Ungarns rigeste mænd, er ganske vist noget svækket efter affæren og også efter EU's kritik af hans finanspolitik, men ventes at fortsætte hele embedsperioden. Fidesz og andre kritikere har samtidig ret $i$, at en del af befolkningen er stærkt desillusioneret af det postkommunistiske socialistparti.

"Mange mennesker vil ikke længere have, at landet styres af forhenværende kommunister", siger lederen af Demokrati-Instituttet i Budapest, Sebestyen Gorka.

\section{Hetz mod mindretal}

\section{Slovakiet vil mange mennesker} ikke have, at landets regering omfatter det højreekstremistiske Nationalparti samt den fhv. ministerpræsident Vladimir Meciars Bevægelse for demokratisk Slovakiet. Men de er med, fordi koalitionens ledende parti, det socialistiske Smer, ellers ikke ville have flertal i parlamentet. Nationalisterne under ledelse af Jan Slota er også uacceptable for Europæiske socialistparti, PES, som derfor har suspenderet Smers medlemskab.

"Smers samarbejde med nationalisterne er i strid med vores principper" begrundede PES' formand, Poul Nyrup Rasmussen, beslutningen, som næsten alle medlemspartier støttede ved afstemningen i oktober.

Smers leder og Slovakiets regeringschef, Robert Fico, var ret utilfreds med PES' afgørelse, men iagttagerne bemærkede dens effekt i Slovakiet - Slota og hans partifæller er nu mere tilbageholdende med perfide udtalelser om mindretallene. Det fem millioner indbyggere store Slovakiet har en halv million etniske ungarere og omtrent ligeså mange romaer.

"Vi er slovakker. Slovakker skal have en slovakisk regering", var et af Slotas slogans under kampagnen op til valget $i$ juni.

Han lovede også at gå af som partiformand, hvis det ungarske parti kom ind i regeringskoalitionen. Det gjorde det ikke, og det er ifølge analytikere grunden til en opblomstring af åbne antiungarske holdninger.

De var indefrosset i de otte år, ungarerne sad i regeringen, men nu er visse grupper aggressive igen, siger en kendt politolog, Ivo Samson.

'Visse grupper' var meget aktive i 
september og oktober, da der kom til flere sammenstød i grænseregionen og verbale skudvekslinger mellem nogle politikere. Men halvfanatiske nationalister findes også i Ungarn, og de gjorde spændingerne endnu værre. De gennemførte flere antislovakiske demonstrationer, og nogle af de udtalelser, som faldt under dem, var på niveau med Slotas tidligere trusler om at jævne Budapest med jorden eller hans tese om, at sigøjnernes eneste mål i tilværelsen er at formere sig og at stjæle.

Hurra-nationalismens bølge har nu lagt sig, og regeringerne i begge lande har taget afstand fra den, men den kan nemt blive fremprovokeret igen, siger eksperter. Og kritikere af Slota siger, at han er et af de mest markante eksempler på Centraleuropas problem med mangelfuld politiske kultur og politisk etik. Men der er også det problem, at hverken Slota eller den polske Liga eller de tjekkiske kommunister, som aldrig har sagt undskyld for deres fælles forbrydelser i fortiden og som er landets tredjestørste parti, stadig har ret mange tilhængere.
Optimister tror, at der er tale om de unge demokratiers børnesygdomme, og at de vil forsvinde relativt hurtigt. Selv den vise og erfarne Bronislaw Geremek tror på en snarlig bedring. De mere skeptiske, som fx den allerede nævnte Richard Falbr, der også er en vis mand, kalkulerer med længere tid.

"Meget af det, vi ser i dag, er en følge af den moralske deformation fra 40 års kommunisme, da vi levede i fuldstændig anormalitet og i permanent løgn og falskhed. Det bliver nok først den næste generation, som bliver helt fri for disse spor. Og der vil komme nye, unge politikere, som vil forstå, at en modstander ikke er ensbetydende med en fjende", sagde Falbr for nylig, da han kommenterede de endeløse regeringsforhandlinger i Prag. Han er selv socialdemokrat ligesom eksregeringschef Jiri Paroubek, som på sjette måned nægter at acceptere sit valgnederlag.

Dana Schmidt er korrespondent for Politiken med Øst- og Centraleuropa som speciale 